\title{
Office of River Protection Monthly Performance Report - September 2000
}
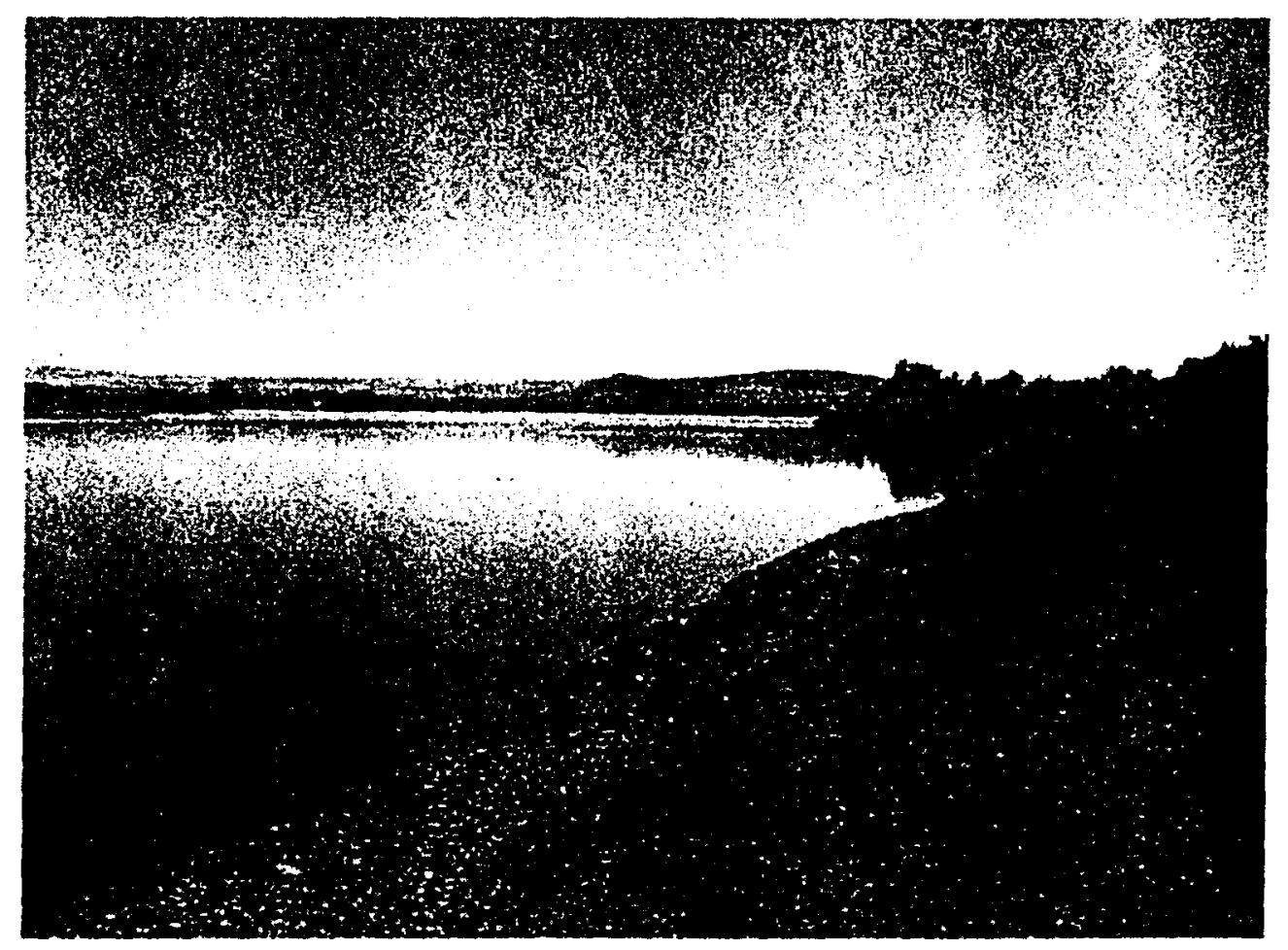

Prepared for the U.S. Department of Energy

Assistant Secretary for Environmental Management

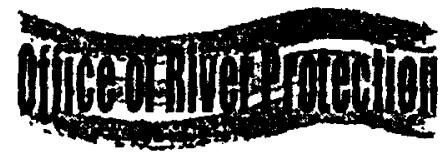

P.O. Box 450

Richland, Washington 99352 


\section{INFORMATION CLEARANCE FORM}

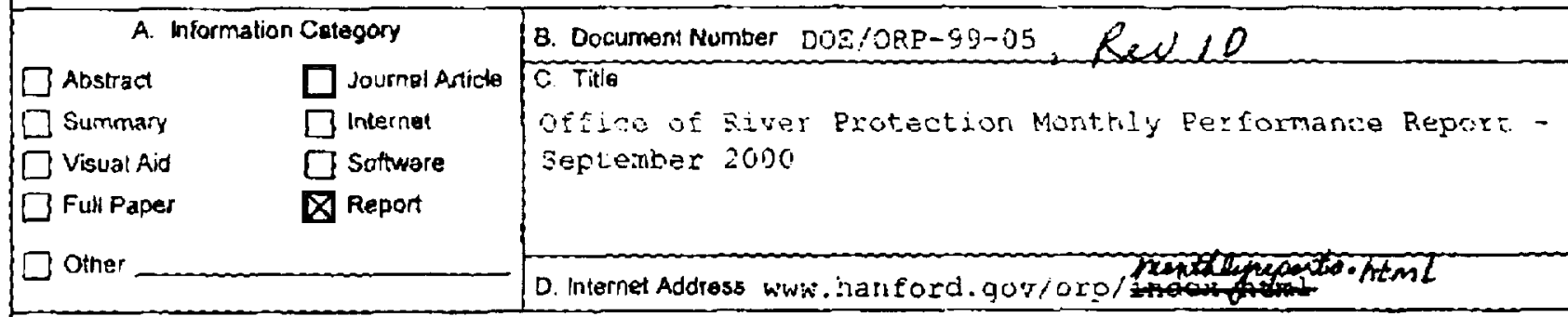

E. Required Information

1. Is pocument potentially classified? ONo Oras (MANDATORY)

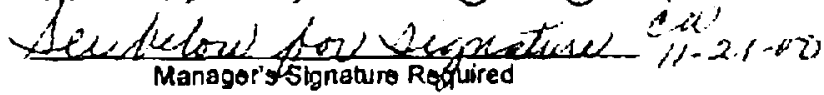
If Yas ADC Signalure Required Qno Ores Classified

2. Inturnal Reviow Required? IVes, Document Signatures Bolow

ONo Ores

Counsel Program

3. References in the information are Apolied Techrology $\mathcal{O}$ No OYes Export Controlled loformation Ono Oyes
4. Does information Contain the Following: (MANDATORY) - New or Novel (Patantable) Subject Matier? ONo OYes If "Yes". Olsctosure No.:

b. Information Recelvad in Confidence, Such as Proprietary andior inventions? ONo OYes II "Yes", Attix Appropriale Legends/Noticas.
c. Copyrights? ONo OYes
(4) "Yes". Attach Permission.
d. Tredemarks? $\mathrm{ONo}$
OYes
"1" "Yes", Identify in Document.

5. Is Information requiring submission to Ostis $O$ No $O$ Yos If Yas $U C_{0}=$

6. Roleose Level? $O$ Pubiic $O$ Limited

7. Charge Code $\frac{120707}{1}$ HFRL009,

f Complete for a Journal Articie

1. Title of Journs

G. Complele for a Presentation

1. Titio tor Conference or Meeting

2 Group Sponsoring

3. Dale of Conference

5. Will Intifmation be Puobshed ig Proceedings? ONo OYes

6. Wul Material be Handed Out? $\bigcirc$ No $O$ Yos

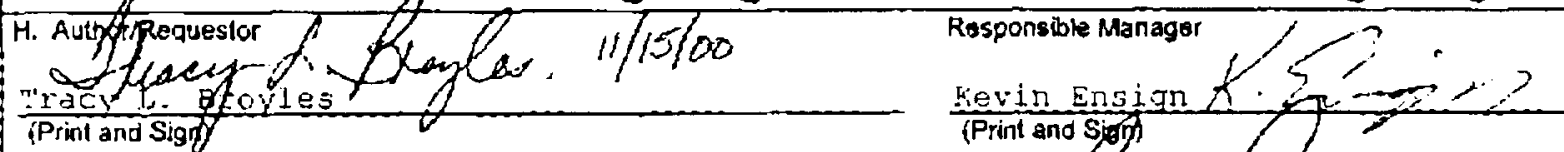

1. Reviewers Yes Pfint

General Counsel $\quad \nabla$ icoct stubbjebine

Ofice of External Affalrs $\otimes$. Eeter Bongtsos

DOE-RL

4. Cityistove

Other

Other

$\square$

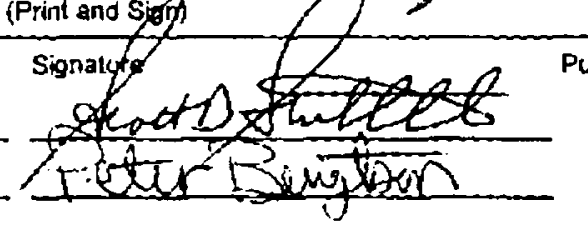

Public YIN (If N, comptete Ji Y $N$

(i) $/ \therefore$

$\mathrm{Y} ; \mathrm{N}$

$\mathrm{i} / \mathrm{N}$

$x / x$

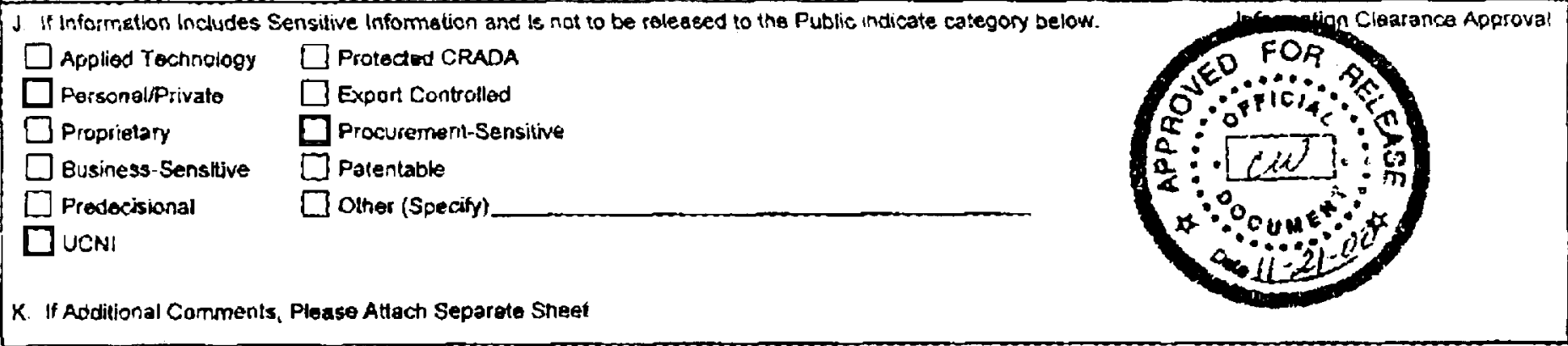


DOE/ORP-99-05

.$\quad$ Revision 10

\section{Office of River Protection Monthly Performance Report - September 2000}

Date Published

November 2000

Prepared for the U.S. Department of Energy Assistant Secretary for Environmental Management

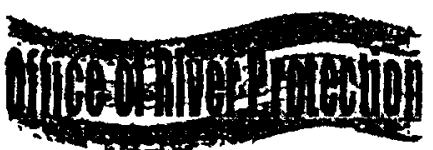

P.O. Box 450

Richland, Washington 99352 


\section{$\cdot$}

LEGAL DISCLAIMER

This report was prepared as an account of work sponsored by an agency of the United States Government. Neither the United States Government nor any agency thereof, nor any of their employees, nor any of their contractors, subcontractors or their employees, makes any warranty, express or implied, or assumes any legal liability or responsibility for the accuracy, completeness, or any third party's use or the results of such use of any information, apparatus, product, or process disclosed, or represents that its use would not infringe privately owned rights. Reference herein to any specific commercial product, process, or service by trade name, trademark, manufacturer, or otherwise, does not necessarily constitute or imply its endorsement, recommendation, or favoring by the United States Government or any agency thereof or its contractors or subcontractors. The views and opinions of authors expressed herein do not necessarily state or reflect those of the United States Government or any agency thereot.

This report has been reproduced from the best available copy. 


\section{RELEASE AUTHORIZATION}

Document Number:

Document Title:
DOE/ORP-99-05, Revision 10

Office of River Protection Monthly Performance

Monthly Report - September 2000

This document, reviewed in accordance with DOE Order 241.1, "Scientific and Technical Information Management," and DOE G 241.1-1, "Guide to the Management of Scientific and Technical Information," does not contain classified or sensitive unclassified information and is:

\section{APPROVED FOR PUBLIC RELEASE}

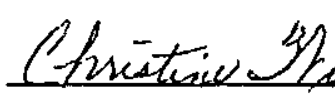

\section{Willingham}

Lockheed Martin Services, Inc.

Information Release

Reviewad for Appled Technobgy, Business Sensitive, Classified, Copynighted, Export Controled, Patent, PersonalPtivate. Proprietery, Protected CRADA, Trademark, Unclassitied Controd Nucker Inlormation.

LEGAL DISCAAIMER. This report was prepered as en account of work sponsored by an agency of the United States Government. Neither the United Stetes Government nor any agency thereol, not any of their empbyees, nor any of their contraclors, subcontractors or their employees. mekes any werrenty, express or impled, or assumes any legal liabilty or responsibilty for the eccurecy, completeness, or eny third pertys use or the results of such use of eny informetion, epperstus, product, or process disclosed, or represents that its use would not infringe privelaly oumed rights. Reference herein to any specific commercial product, process, or cenvice by trade name, tredemerk, menufacturer, or otherwise, does not necesserity constitule or imply its endorsement, recommendetion, or favoring by the United Stales Government or any epency thereof or its contractors or subcontraciors. The views end opinions of authors expressed herein do not neccesserily stale or reflect those of the United Slates Government or any egency thereof.

This report has been reproducod from the best aveileble copy.

Printed in the United States of America. 


\section{RIVER PROTECTION PROJECT WBS 1.1}

\section{PROJECT MANAGERS:}

H. L. Boston, Acting Manager DOE-Office of River Protection Phone: (509) 376-6677

M. P. Delozier President and General Manager CH2M HILL Hanford Group, Inc. Phone: (509) 372-8061 


\section{Table of Contents}

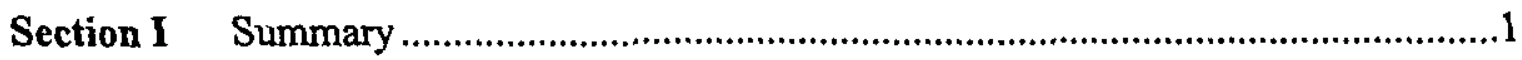

Upcoming Key Planned Events ......................................................................4

Section II Feed Delivery (CH2M HILL Hanford Group, Inc.)

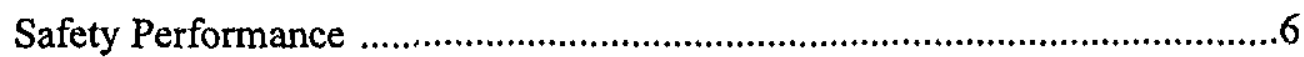

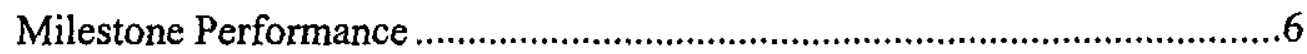

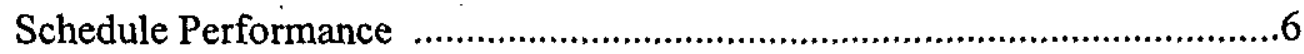

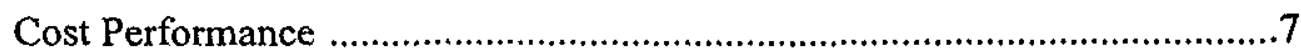

Feed Delivery Cost/Schedule Performance (CHG Only) ..............................8

Feed Delivery Cost/Schedule Performance (Inc. Direct Funded Activities)..9

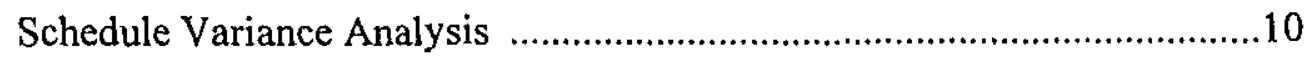

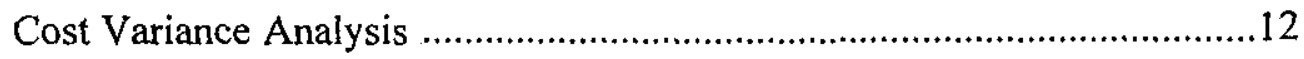

Milestone Achievement .....................................................................

Section III Waste Treatment and Immobilization Plant (WTP)

WTP Cost/Schedule Performance .............................................................

WTP Upcoming Key Planned Events.........................................................18 


\section{Section I}

\section{Summary}




\section{SUMMARY $\quad$.}

$\mathrm{CH} 2 \mathrm{M}$ Hill Hanford Group, Inc. (CHG) had an outstanding year. The most significant accomplishments that occurred throughout fiscal year (FY) 2000 include the following:

On April 24, 2000, DOE ORP received BNFL Inc. B-1 deliverables and CHG completed Phase 1 Part B-2 Readiness-to-Proceed (RTP), to demonstrate the ability to provide waste feed to be treated/stored in a long-term disposal facility. The RTP consisted of key enabling assumptions, critical risks, waste handling actions, financial and schedule risk analysis, staffing plans, a project execution plan, and a resource loaded schedule.

The Department determined that the BNFL Inc. proposal was unacceptable in many areas and essentially shifted the financial risk from BNFL Inc. back to the Federal government; thus a key benefit of privatization was lost. On May 8, 2000, the Secretary announced that the privatization contract be terminated.

In the interim, the Department directed the onsite Tank Farm Contractor, CHG, to continue the design work scope for the Waste Treatment and Immobilization Plant until a new waste treatment contract is awarded.

DOE ORP released its request for proposals (RFP) for a new Waste Treatment and Immobilization contractor on August 31, 2000 and is on schedule to meet award of the contract by January 15, 2000.

CHG successfully reached $1,000,000$ safe work hours without a lost workday injury or illness on Wednesday, September 23,2000. The record was initiated on May 23, 2000 and took 114 days to achieve. This is the third time in the past three years that this milestone has been achieved. In addition, for the first time in the history of the Hanford tank farms, $\mathrm{CHG}$ achieved 1,000,000 work hours without a restricted workday. More than 1,400 employees worked 108 consecutive days without an injury that would require a restriction or light-duty assignment from their normal duties. This happened through intense work efforts such as: transitioning to a new project organization, saltwell pumping, cross-site transfers, initiating work on interim vitrification plant design and construction, vadose zone sampling in SX tank farm, continuing progress on Project W-314, "Tank Farm Restoration and Safe Operations," and significant construction efforts on infrastructure for the vitrification plant. CHG is achieving work with record productivity and record safety performance. This success is attributed to focusing on the new mission of Safe Project Delivery.

All Tri-Party Agreement and Consent Decree milestones scheduled for the fiscal year were completed. Along with meeting all enforceable agreement milestones, nineteen out of twenty Performance Incentives (PIs) were successfully completed. The 20 PIs comprised of 114 specific deliverables, of which 107 were met. In addition to the 20 scheduled PIs, six accelerated activities were completed.

Tank 241-SY-101 hydrogen generation was successfully mitigated this fiscal year, including a series of transfers and back-dilutions that remediated the flammable gas hazards and closed the surface level growth Unreviewed Safety Question (USQ) associated with the tank.

CHG transitioned from the Basis for Interim Operation to the Final Safety Analysis Report (FSAR) in October 1999.

The High Heat Safety Issue on tank 241-C-106 was resolved, including the removal of the tank from the watch list. 


\section{SUMMARY (continued)}

Several cross-site waste transfers were completed to support saltwell pumping efforts. In addition, Evaporator Campaign 00-1 began in April 2000, resulting in an estimated waste volume reduction of 600,000 gallons.

Final sluicing operations of tank 241-C-106 were completed on October 6, 1999. The sludge recovery goal of 95 percent was exceeded. The total sludge transfer from tank 241-C-106 to 241-AY-102 was 67.8 inches (186,500 gallons).

The successful test of the AZ-101 mixer pump was completed, proving that CHG has the technology necessary to retrieve tank waste for treatment.

Approval of the Notice of Construction (NOC) for the AN Farm tank retrieval system was received from the U.S Department of Energy (DOE) and the Environmental Protection Agency on July 21, 2000. This is a significant step forward for Project W-211, "Initial Tank Retrieval Systems" in preparing waste for delivery to the Waste Treatment and Immobilization Plant.

CHG fully supported the DOE-Office of River Protection (ORP) in establishing a Project Integration Office (PIO). The PIO function is to interface with DOE-ORP and CHG to achieve mission success for the River Protection Project.

The Interim Stabilization Project pumped approximately 70,000 gallons from four tanks in the month of September 2000. Project-to-date (since June 1998) volume pumped is approximately 977,000 gallons. Six tanks have been interim stabilized this fiscal year. Tanks 241-S-106 and 241-U-105 are being evaluated to determine if the stabilization criteria have been met. Out of the 149 single-shell tanks (SSTs), 125 tanks have been stabilized. Pumping this waste from the single-shell tanks to more secure double-shell tanks (DSTs) supports stabilization of the waste tanks and mitigates leakage to the environment. The Interim Stabilization Project is planned to complete by September 2004.

Waste Characterization obtained two grab samples and one vapor sample in the month of September 2000. A total of 16 core samples, 16 grab samples, and 10 vapor samples were taken this fiscal year in support of three key FY 2000 sampling milestones. Milestone T01-00-107, to complete 12 core samples, was achieved six months ahead of schedule. Milestone T01-00-108, to complete $12 \mathrm{grab}$ samples, and T01-00-109, to complete six vapor samples by September 29, 2000, were both completed three months ahead of schedule. In addition, all 24 planned Lab Analysis Reports (LARs). Two additional LARs were completed by the end of the fiscal year.

The Waste Retrieval Project completed the Functions and Requirements (F\&R) document and Project Execution Plan for tank 241-C-104; completed the F\&R document for the tank 241-S-103 retrieval demonstration; and completed the advanced conceptual design for Project W-521, "Waste Feed Delivery Systems."

Excellent progress was made on the infrastructure project (Project W-519) for the vitrification plant this fiscal year, including completion of access roads, and raw and potable water lines. In addition, final Effluent Transfer System design modifications were received and approved, construction of the electrical substation basement floor and walls was completed; and foundations for the power circuit breakers were completed in September 2000 . 


\section{SUMMARY (continued)}

The Immobilized Waste Storage and Disposal Project also had an outstanding year, including the accomplishment of the following significant milestones: completion of strategies and plans for disposal of High Level Waste (HLW) and Low Activity Waste (LAW) melters, and Immobilized High Level Waste (IHLW)/Immobilized Low Activity Waste (ILAW) sample transportation and disposition; issuance of final IHLW and ILAW Program Plans; completion of a study evaluating the use of the Fuels and Materials Examination Facility (FMEF) for IHLW storage; approval from DOE-ORP of the ILAW Disposal Facility Closure Plan; issuance of the Remote Handled ILAW Disposal Facility PreOperational Monitoring Plan; and completed a compressive strength study for the ILAW remote handled waste trench. 


\section{UPCOMING KEY PLANNED EVENTS IN THE NEXT 90 DAYS}

- Waste Treatment and Immobilization Plant proposals due to DOE ORP on October 20, 2000.

- Core sample tank 241-SY-102, and grab sample tanks 241-SY-102 and 241-TX-244 (October).

- Prepare basis for waste and activity-based flammable gas safety analysis methodology (October).

- Start interim stabilization of tanks 241-A-101, 241-AX-101, and 241-SX-103 (October).

- Initiate Waste Treatment and Immobilization Plant Optimization Studies (October).

- Begin excavation for double pipe containment systems and non-dangerous waste line (Privatization Infrastructure) (October).

- Initiate Level I Specification and Project W-520, "ILAW Disposal Facility" Conceptual Design Review activities (October).

- Grab sample tank 241-AP-104, and vapor sample tanks 241-AX-152 and 241-AP-104 (November).

- Submit the Authorization Basis (AB) amendment and topical report for the Organic Complexant USQ on Inactive Miscellaneous Underground Storage Tanks (IMUSTs) (November).

- Obtain approval and implement the $\mathrm{AB}$ amendment for the new salt well pump design (November).

- Start interim stabilization of tank 241-SX-101 (November).

- Lay and test double pipe containment system (Privatization Infrastructure) (November).

- Grab sample tanks 241-SY-102 and 241-AP-107, and core sample tank 241-C-107 (December).

- Submit the Basis for Interim Operation (BIO) reconciliation AB amendment (December).

- Start interim stabilization of tank 241-U-106 (December).

- Develop a path forward to remove the organic layer from tank 241-C-103 (December).

- Receive and install transmission towers (Privatization Infrastructure) (December).

- Deliver the draft 2001 Performance Assessment (PA) to DOE-ORP for review (December).

- Resume operations and design critical path activities leading to the initiation of construction of the Waste Treatment and Immobilization Plant (on-going). 


\section{Section II}

\section{Feed Delivery}

\section{CH2M HILL Hanford Group, Inc. (CHG)}

\section{PROJECT MANAGER:}

M. P. Delozier President and General Manager CH2M HILL Hanford Group, Inc. Phone: (509) 372-8061 


\section{Feed Delivery - CH2M HILL Hanford Group. Inc. (CHG)}

\section{SAFETY PERFORMANCE}

CHG successfully reached $1,000,000$ safe work hours without a lost workday injury or a restricted workday. Six first aid cases and four OSHA recordable cases were reported in the month of September 2000. The majority of the cases resulted from minor cuts, strains, and repetitive motion to workers in the field. The first aid case rate decreased by six from August to September, and the 12-month rolling average lost workday rate decreased from 0.47 in August to 0.39 in September 2000. This trend continues to decline and approaches the Savannah River Site average of 0.37 . Safety behavior dramatically improved over the last six months as a result of increased management and worker attention; and focused safety corrective action meetings. The all day safety event, "Communicate the Commitment Day," held on June 16,2000, proved to heighten safety awareness and enforce the importance of safety as the number one priority for all CHG employees. The goal for FY 2001 is to continue this excellent safety record and awareness.

\section{MILESTONE PERFORMANCE}

CHG had 67 reportable milestones scheduled for FY 2000, consisting of 15 Enforceable Agreement milestones and 52 ORP-level milestones. Thirty-five milestones were completed early, twenty-four milestones were completed on schedule, four milestones were completed late, and four milestones were missed. The four uncompleted ORP-level milestones (T03-00-755, "FY 2000 Quarter 3 - maintain average pump efficiency of 50\%," due June 30, 2000; T04-00-106, "Review BNFL deliverables and perform a gap analysis," due June 15, 2000; T04-00-343, "Develop SST Program Capabilities and Evaluation," due September 30, 2000; and T06-00-101, "Construction authorization program review/decision," due August 24, 2000), were missed due to saltwell pumping equipment problems, renegotiations of the SST program, and DOE-ORP cancellation of the BNFL contract. The BNFL gap analysis is being deleted (per DOE-ORP direction) via change control. SST milestones have been reestablished, and the vitrification plant construction authorization milestone will be re-established in FY01. Baseline change request RPP-00-139, approved on September 13, 2000, moved ORP-level milestone T01-00-114, contractor deliverable for M-44-15D, due September 20, 2000, to October 20, 2000.

\section{SCHEDULE PERFORMANCE (\$M)}

\begin{tabular}{|l|c|c|c|}
\hline & BCWP & BCWS & VARIANCE \\
\hline RPP TOTAL & $\$ 388.5$ & $\$ 399.0$ & $(\$ 10.5)$ \\
\hline
\end{tabular}

\section{SCHEDULE VARIANCE}

The majority of the $\$ 10.5$ million (-2.6 percent) unfavorable schedule variance is within Waste Characterization, Safety Issue Resolution, Tank Farm Operations, and Waste Retrieval. The unfavorable schedule variance is due to non-PI related scope for grab sample data packages and lab analysis being behind schedule; 241-SY-101 scope not completed; Project W-314, "Tank Farm Restoration and Safe Operations," SN transfer line and piping issues; Environmental, Safety, Health, and 


\section{SCHEDULE VARIANCE (Continued)}

Quality (ESH\&Q) activities being behind schedule due to diversion of resources to support higher priority emergent work scope earlier in the fiscal year (tank 241-SY-101 pumping, cross-site waste transfers, and 244-AR vault activities); and Resource Conservation and Recovery Act (RCRA) Part B Permit activities being behind schedule due to delays in receiving comments from Ecology. Finally, the unfavorable schedule variance in Waste Retrieval is due to cancellation of the Readiness-to-Proceed (RPT2) gap analysis due to the vitrification contract change; the final 241-AZ-101 report being behind schedule due to a backlog at the lab; and reassignment of support staff to higher priority work.

COST PERFORMANCE (\$M)

\begin{tabular}{|l|c|c|c|}
\hline & BCWP & ACWP & VARIANCE \\
\hline RPP TOTAL & $\$ 388.5$ & $\$ 354.9$ & $\$ 33.6$ \\
\hline
\end{tabular}

\section{COST VARIANCE}

The favorable cost variance of $\$ 33.6$ million ( +8.7 percent) results from a credit passback of approximately $\$ 6.0 \mathrm{M}$ for approved reductions in the Fluor Hanford and $\mathrm{CHG}$ overhead pools; and efficiencies of approximately $\$ 16 \mathrm{M}$ realized in core sampling; program management activities; flammable gas activities; Project W-211, "Initial Tank Retrieval Systems" design activities; Project W-519, "Vitrification Plant Infrastructure" construction; ILAW/IHLW engineering studies; systems engineering and technical baseline efforts, and Project Integration Office activities. Efficiencies were used to complete accelerated baseline work scope.

The remainder of the favorable cost variance is within Privatization Phase II, resulting from subcontract costs being less than estimated for research and technology activities resulting from delays in awarding the contract, and less than planned staff to support interim design activities. Contracts will be awarded, and appropriate staff will support work scope needs. 


\section{FY2000 Cost/Schedule Performance - All Fund Types CH2M HILL Hanford Group, Inc. Only \\ Cumulative Status to Date (Dollars in Millions)}

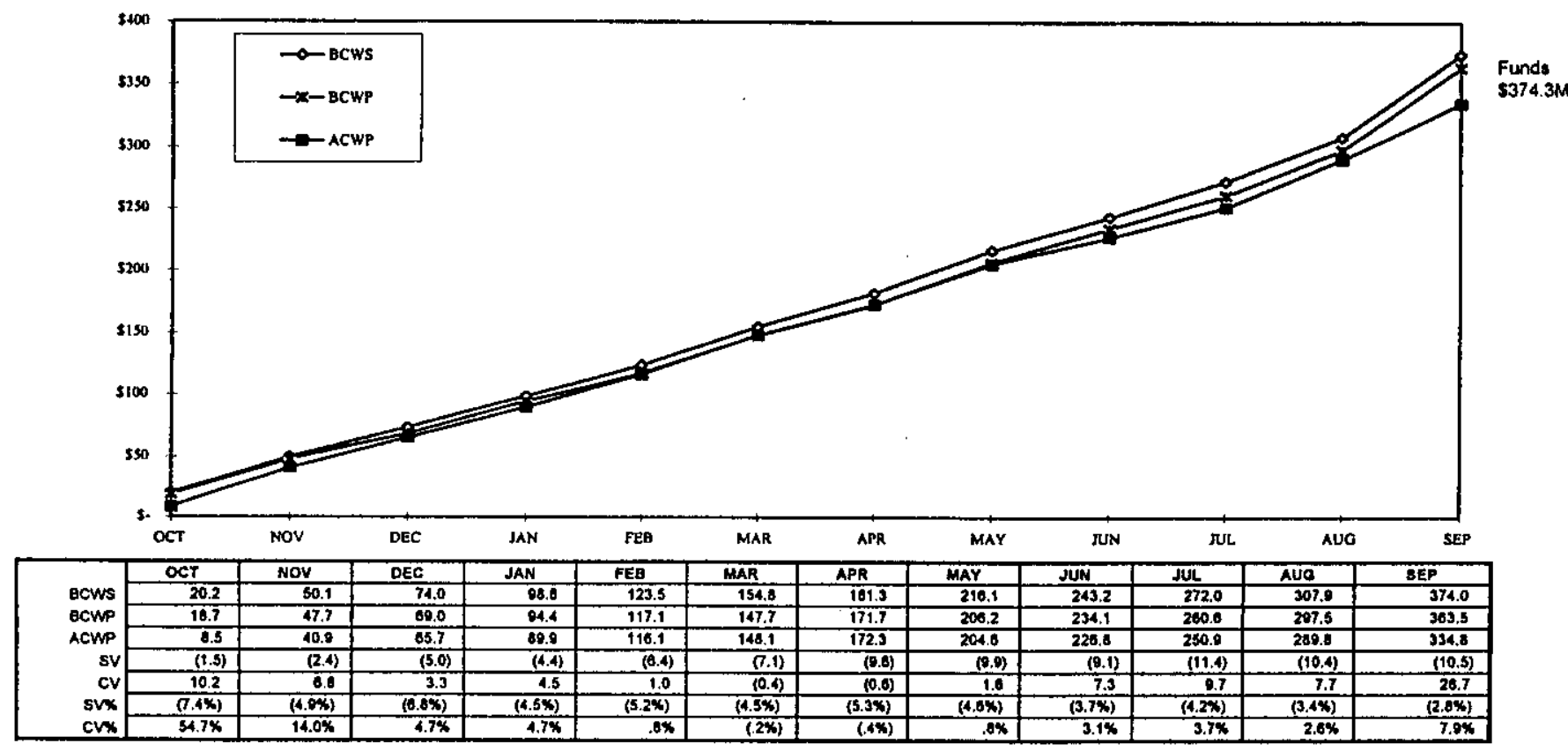

FY 2000 Cost/Schedule Performance - All Fund Types CH2M HILL Hanford Group, Inc. Only Cumulative Status to Date (Dollars in Millions)

\begin{tabular}{|c|c|c|c|c|c|c|c|c|c|c|c|}
\hline \multicolumn{2}{|c|}{ PEAF-SEPTOOCACA) } & \multicolumn{8}{|c|}{ FISCAL YEAR TO DATE } & \multicolumn{2}{|c|}{ ANNUAL OATA } \\
\hline & \multirow[b]{2}{*}{ PBS / TITLE } & \multicolumn{2}{|c|}{$\begin{array}{l}\text { BUDGET } \\
\text { COST }\end{array}$} & \multirow{2}{*}{$\begin{array}{c}\text { ACTUAL } \\
\text { COST } \\
\text { WORK } \\
\text { PERF } \\
\end{array}$} & \multicolumn{5}{|c|}{ VARIANCE } & \multirow[b]{2}{*}{$\begin{array}{c}\text { CURRENT } \\
\text { BAC } \\
\end{array}$} & \multirow[b]{2}{*}{ FUNDING } \\
\hline & & $\begin{array}{l}\text { WORK } \\
\text { SCHED }\end{array}$ & $\begin{array}{l}\text { WORK } \\
\text { PERF }\end{array}$ & & SCHED & $\begin{array}{c}\text { SCHEO } \\
\alpha^{\prime} \\
\end{array}$ & $\cos$ & $\begin{array}{c}\cos T \\
x^{\prime}\end{array}$ & & & \\
\hline TWO1 & TANK WASTE CHARACTERIZATION & 34.3 & 33.4 & 29.4 & $(0.8)$ & $(2.6) \%$ & 4.0 & 12.1 & $\%$ & 34.3 & 30.2 \\
\hline TWO2 & TANK SAFETY ISSUE RESOLUTION & 23.1 & 22.1 & 19.6 & $(1.0)$ & $(4.3) \%$ & 2.5 & 11.0 & $\%$ & 23.1 & 21.4 \\
\hline \multirow[t]{4}{*}{ TW03 } & TANK FARM OPERATIONS & 139.0 & 133.8 & 135.8 & $(5.1)$ & $(3.7) \%$ & $(1.7)$ & $(1.3)$ & $\%$ & 139.0 & 130.3 \\
\hline & W-058-Croses Site Xfer-LI & 0.0 & 0.0 & $(0.1)$ & 0.0 & $0.0 \%$ & 0.1 & 0.0 & $\%$ & 0.0 & (0.1) \\
\hline & $W \cdot 314 \cdot T F$ Rest'n-LI & 23.1 & 21.0 & 19.6 & $(2.1)$ & $(9.1) \%$ & 1.4 & 6.6 & $\%$ & 23.1 & 21.2 \\
\hline & TOTAL OPS & 1621 & 154.9 & 155.1 & $(7.2)$ & $(4.4) \%$ & $(0.2)$ & $(0.1)$ & $\%$ & 152.1 & 151.3 \\
\hline \multirow[t]{3}{*}{ TWO4 } & RETRIEVAL. & 51.2 & 50.2 & 46.0 & $(1,0)$ & $(2.0) \%$ & 4.2 & 8.3 & \% & 51.2 & 48.0 \\
\hline & W.211 - InIt Tank Ret'vI Sys-LI & 6.0 & 6.0 & 5.1 & 0.0 & $0.0 \%$ & 0.8 & 16.2 & $\%$ & 6.0 & 14.8 \\
\hline & TOTAL RETRIEVAL & 572 & 56.2 & 51.1 & $(1.0)$ & $(1,8) \%$ & 5.1 & 9.2 & $\%$ & 572 & 62.9 \\
\hline TWOS & PROCESS WASTE SUPPT & 13 & 13 & 1.0 & 0.0 & $0.0 \%$ & 0.3 & 28.8 & $\boldsymbol{*}$ & 1.3 & 1.1 \\
\hline \multirow[t]{3}{*}{ TWOB } & PRIVAT'ZN INFRASTRUCTURE & 2.2 & 2.2 & 1.6 & $(0.0)$ & $(0.8) \%$ & 0.6 & 26.7 & $\%$ & 2.2 & 2.3 \\
\hline & W.519-PrIv Infra Spt -LI & 11.3 & 11.3 & 9.3 & 0.0 & $0.0 \%$ & 2.0 & 17.5 & $\%$ & 11.3 & 16.1 \\
\hline & TOTAL INFRASTRUCTURE & 13.5 & 13.5 & 10.9 & $(0.0)$ & $(0.1) \psi_{6}$ & 2.6 & 18.8 & $\%$ & 13.5 & 18.4 \\
\hline TWO9 & IMMOBILIZED TANK WASTE & 8.5 & 8.5 & 7.6 & $(0.0)$ & $(0.3) \%$ & 0.8 & 11.2 & $\%$ & $\mathbf{8 . 5}$ & 7.8 \\
\hline \multirow[t]{5}{*}{ TW 10} & RPP MANAGEMENT SUPPORT & 42.8 & 42.2 & 383 & $(0.4)$ & $(0.9) \%$ & 3.8 & 8.1 & $\%$ & 42.6 & 38.9 \\
\hline & & 0.0 & 0.0 & 0.0 & 0.0 & $0.0 \%$ & 0.0 & 0.0 & $\%$ & 0.0 & 7.6 \\
\hline & TOTAL EXPENSE/CENRTC & 302.2 & 293.8 & 278.1 & $(8.4)$ & $(2.8) \%$ & 14.7 & 6.0 & $\%$ & 202.2 & 287.7 \\
\hline & TOTAL LINE ITEM & 40.4 & 38.3 & 34.0 & $(2.1)$ & $(5.2) \%$ & 4.3 & 11.6 & $\%$ & 40.4 & 52.1 \\
\hline & TOTAL RPP - WIO TWOB & $\begin{array}{l}342.6 \\
== \pm=\end{array}$ & $\begin{array}{l}332.1 \\
x=1=x\end{array}$ & $\begin{array}{l}313.1 \\
==1=\end{array}$ & $\begin{array}{l}(10.5) \\
=x=x=\end{array}$ & $\underbrace{(3.1)}_{-=1} \%$ & $\begin{array}{r}19.0 \\
=\pi=\end{array}$ & $\begin{array}{r}5.8 \\
m=\infty \pi\end{array}$ & \% & $\begin{array}{l}342.6 \\
==2 \times=\end{array}$ & $\begin{array}{r}339.8 \\
-2=0\end{array}$ \\
\hline \multirow[t]{4}{*}{ TWOB } & PRIVAT'ZN PHASE ! & 31.4 & 31.4 & 21.7 & 0.0 & $0.0 \%$ & 9.7 & 30.7 & $\%$ & 31.4 & 34.5 \\
\hline & TOTAL EXPENSE/CENRTC & 333.6 & 325.2 & 300.8 & $(8.4)$ & $(2,8) \times$ & 24.4 & 7.8 & * & 333,6 & 322.2 \\
\hline & TOTAL LINE ITEM & 40.4 & 38.3 & 34.0 & $(2.1)$ & $(5.2) \%$ & 4.3 & 11.6 & $\%$ & 40.4 & 52.1 \\
\hline & TOTAL RPP - WITWOG & $\begin{array}{l}374.0 \\
-=0\end{array}$ & $\begin{array}{r}363.5 \\
x=0.4\end{array}$ & $\begin{array}{r}334.8 \\
=3 \approx= \\
\end{array}$ & $\begin{array}{l}(10.5) \\
=\pi=5\end{array}$ & $\underset{=1}{(2.8) *} \times$ & $\begin{array}{r}28.7 \\
-0=0 \\
\end{array}$ & $\begin{array}{r}7.9 \\
=-1=0 \\
\end{array}$ & * & $\begin{array}{l}374.0 \\
==2=\end{array}$ & $\begin{array}{r}374.3 \\
m=1=\end{array}$ \\
\hline
\end{tabular}




\section{FY 2000 Total Cost/Schedule Performance - All Fund Types (Including All Direct Funded Activities) \\ Cumulative to Date Status (Dollars in Millions)}

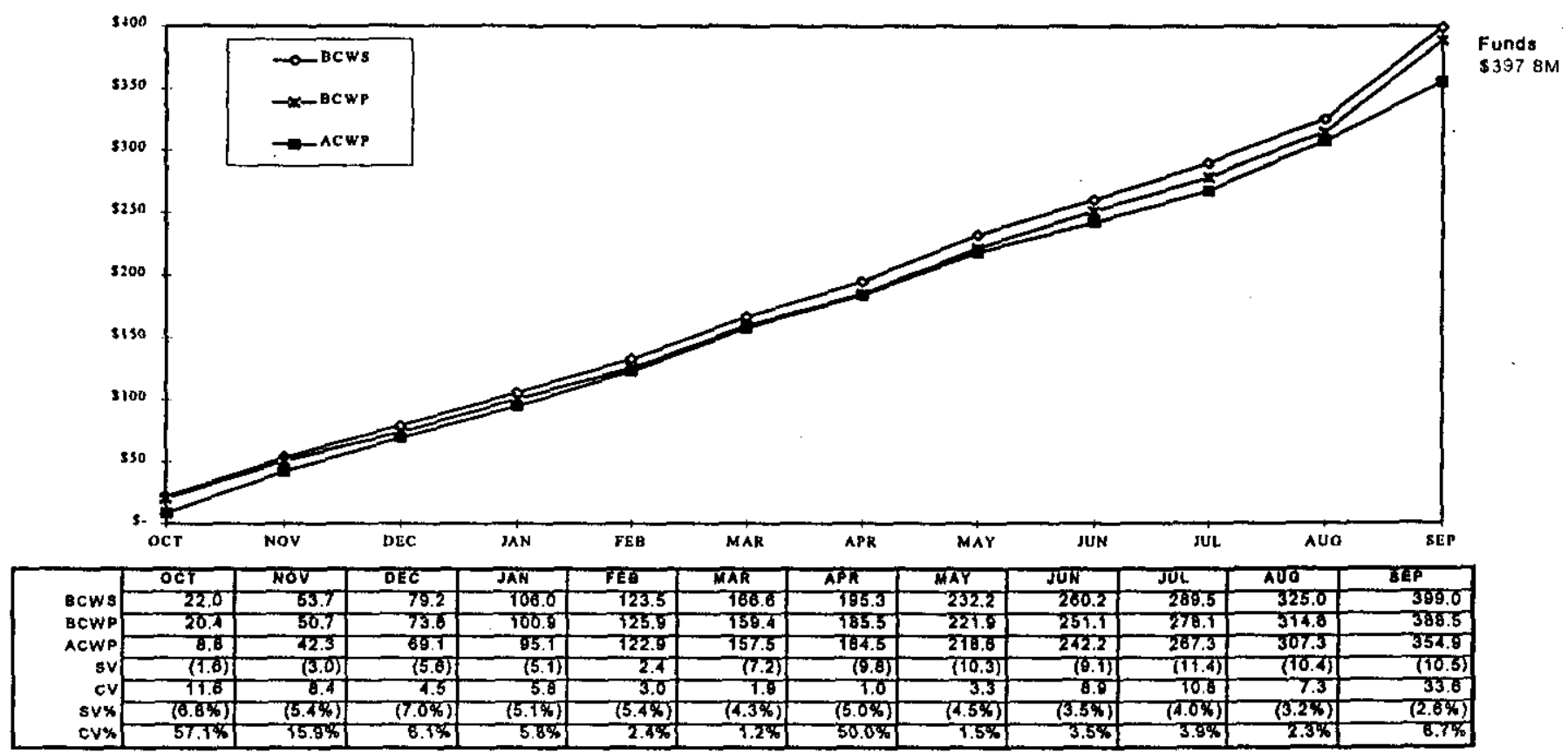

FY 2000 Total Cost/Schedule Performance - All Fund Types

(Including All Direct Funded Activities)

Cumulative Status to Date (Dollars in Millions)

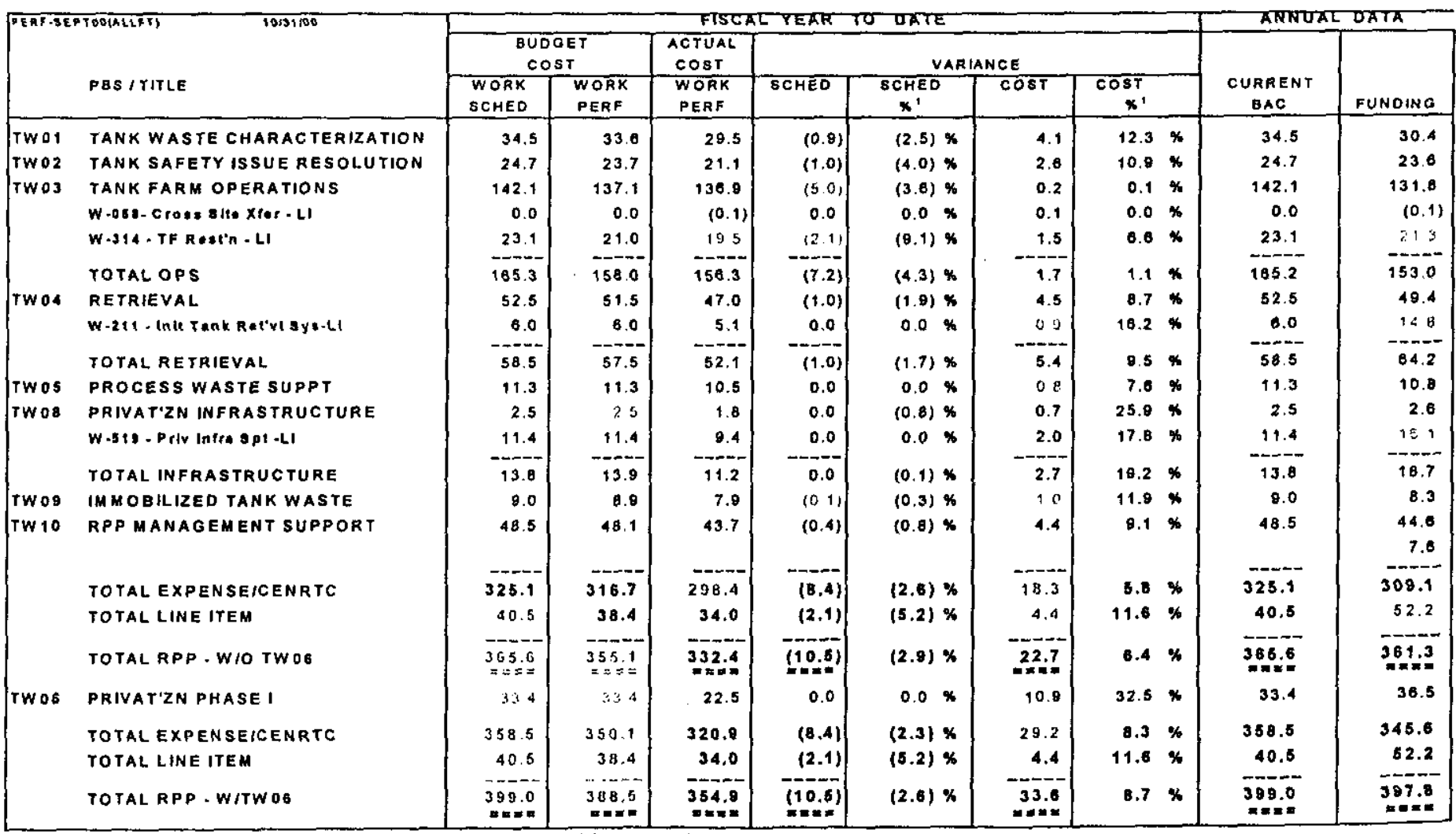




\section{SCHEDULE VARIANCE ANALYSIS (\$10.5M)}

\section{WBS/PBS $\quad$ Title}

\subsubsection{1/TW01 Tank Waste Characterization}

Description and Cause: The unfavorable schedule variance $(-\$ 0.8 \mathrm{M} ;-2.5 \%)$ is due to non-PI related scope for grab sample data packages and lab analysis being behind schedule.

Impacts: No milestones are impacted.

Corrective Action: None required. All FY 2000 milestones were completed.

\subsubsection{2/TW02 Tank Safety Issue Resolution}

Description and Cause: The unfavorable schedule variance $(-\$ 1.0 ;-4.0 \%)$ is within the reporting threshold of negative 7.5 percent; however, the majority of the schedule variance is due to deferring 241-SY-101 scope to FY01.

Impacts: There are no impacts.

Corrective Action: None required, as the scope will be completed in FY 2001.

\subsubsection{3/TW03 Tank Farm Operations}

Description and Cause: The unfavorable schedule variance $(-\$ 7.2 \mathrm{M} ;-4.3 \%)$ results from the following. Project W-314, "Tank Farm Restoration and Safe Operations," due to SN transfer line and piping issues; Interim Stabilization, due to pump and transfer line failures; work on Project W-420, Stack Monitoring System Upgrades, is on hold pending approval of a path forward plan from DOEORP; and Environmental, Safety, Health, and Quality (ESH\&Q) activities (internal and external assessments) are behind schedule due to diversion of resources to support higher priority emergent work scope earlier in the fiscal year (tank 241-SY-101 pumping, cross-site waste transfers, and 244-AR vault activities). Finally, RCRA Part B Permit activities are behind schedule due to delays in receiving comments from Ecology.

Impacts: There are no impacts, as all planned milestones were completed.

Corrective Action: None required.

\subsubsection{4/TW04 Retrieval Project}

Description and Cause: The unfavorable schedule variance $(-\$ 1.0 \mathrm{M} ;-1.7 \%)$ is due to the following: Cancellation of the Readiness-to-Proceed (RPT2) gap analysis due to the vitrification contract change; the final 241-AZ-101 report being behind schedule due to a backlog at the lab; and reassignment of support staff to higher priority work.

Impacts: There are no impacts; as all planned milestones were completed.

Corrective Action: None required, as the final 241-AZ-101 report will be completed in FY01.

\subsubsection{5/TW05 Process Waste Support}

Description and Cause: There is no schedule variance; therefore, no explanation is required.

Impacts: None required.

Corrective Action: None required.

\subsubsection{6/TW06 Privatization Phase I}

Description and Cause: There is no schedule variance; therefore no explanation is required.

Impacts: None required.

Corrective Action: None required. 


\section{SCHEDULE VARIANCE ANALYSIS (\$10.5M)}

(Continued)

WBS/PBS

Title

\subsubsection{8/TW08 Privatization Infrastructure}

Description and Cause: There is no schedule variance; therefore no explanation is required.

Impacts: None required.

Corrective Action: None required.

\subsubsection{9/TW09 Immobilized Waste}

Description and Cause: The unfavorable schedule variance $(-\$ 0.1 \mathrm{M} ;-0.3 \%)$ is within the reporting threshold; therefore, no explanation is required at this time.

Impacts: None required.

Corrective Action: None required.

1.01.10/TW10 Management Support

Description and Cause: The unfavorable schedule variance $(-\$ 0.4 \mathrm{M} ;-0.8 \%)$ is within the reporting threshold; therefore, no explanation is required.

Impacts: None required.

Corrective Action: None required. 


\section{COST VARIANCE ANALYSIS $(\$ 33.6 \mathrm{M})$}

\subsubsection{1/TW01 Tank Waste Characterization}

Description and Cause: The favorable cost variance $(\$ 4.1 \mathrm{M} ; 12.3 \%)$ is due to a credit passback for approved reductions in the Fluor Hanford and CHG overhead pools; and efficiencies in core sampling operations driven by the elimination of several planning packages for equipment set-up and tear-down, thus reducing planning and craft labor costs. Additional cost savings are reflected in Program Management and data development activities as a result of labor underruns. The positive cost variance is partially offset by higher than anticipated costs from the 222-S laboratory, resulting from overtime and expedited service on lab assessments.

Impacts: There are no impacts.

Corrective Action: None required. Efficiencies were used to perform emerging and accelerated work scope.

\subsubsection{2/TW02 Tank Safety Issue Resolution}

Description and Cause: The favorable cost variance $(\$ 2.6 \mathrm{M} ; 10.9 \%)$ is due to a credit passback for approved reductions in the Fluor Hanford and CHG overhead pools; and efficiencies in Flammable Gas activities.

Impacts: There are no impacts.

Corrective Action: None required. Efficiencies were identified for re-allocation to other high priority CHG needs.

\subsubsection{3/TW03 Tank Farm Operations}

Description and Cause: The favorable cost variance $(\$ 1.7 \mathrm{M} ; 1.1 \%)$ is within the reporting threshold of positive 10 percent; therefore, no explanation is required.

Impacts: None required.

Corrective Actions: None required.

\subsubsection{4/TW04 Retrieval Project}

Description and Cause: The favorable cost variance $(\$ 5.4 \mathrm{M} ; 9.5 \%)$ is due to a credit passback for approved reductions in the Fluor Hanford and CHG overhead pools; retrieval technical evaluations were performed by Tank Focus Area resources; efficiencies were achieved in several engineering tasks including the cold test facility activity. and Project W-211, "Initial Tank Retrieval Systems" realized efficiencies on Title II designs for the AZ-102, AN-104, AP-102/104 retrieval systems from lessons learned on previous designs. In addition, a contract for Project W-523, SST High Level Waste Retrieval System, Phase 1 project definition support was awarded for less than what was estimated.

Impacts: There are no impacts.

Corrective Action: None required.

\subsubsection{5/TW05 Process Waste Support}

Description and Cause: The favorable cost variance $(\$ 0.8 \mathrm{M} ; 7.6 \%)$ is within the reporting threshold of positive 10 percent; therefore no explanation is required.

Impacts: None required.

Corrective Action: None required. 


\section{COST VARIANCE ANALYSIS \$33.6M}

(Continued)

\section{WBS/PBS}

\subsubsection{6/TW06}

Description and Cause: The favorable cost variance $(\$ 10.9 \mathrm{M} ; 32.5 \%)$ is due to subcontract costs being less than estimated for research and technology activities due to delays in awarding the contract, and less than planned staff to support interim design.

Impacts: There are no impacts.

Corrective Action: Contracts will be awarded, and appropriate staff will support work scope needs.

\subsubsection{8/TW08 Privatization Infrastructure}

Description and Cause: The favorable cost variance $(\$ 2.7 \mathrm{M} ; 19.2 \%)$ is due to Program Management efficiencies resulting from better utilization of existing staff; a favorable habitat mitigation fixed price contract; and an underrun due to a favorable bid on the electrical system design for Project W-519. In addition, procurements scheduled for September were not received.

Impacts: There are no impacts.

Corrective Action: CHG has requested DOE-ORP to reprogram approximately $\$ 4 \mathrm{M}$ of capital line item funding from Project W-519 to expense for other higher priority work.

\subsubsection{9/TW09 Immobilized Tank Waste}

Description and Cause: The favorable cost variance $(\$ 1.0 \mathrm{M} ; 11.9 \%)$ is due to a credit passback for approved reductions in the Fluor Hanford and CHG overhead pools; efficiencies in program management, and ILAW and IHLW engineering studies (sample transport and melter strategy) resulting from better utilization of existing staff (by using similar studies, and having staff more familiar with the work); and a reduction in personnel within the ILAW program. In addition, geotechnical data packages and wind/stack/thermal analysis activities cost less than anticipated.

Impacts: There are no impacts.

Corrective Action: Efficiencies were used for other higher priority $\mathrm{CHG}$ work.

\subsubsection{0/TW10 Management Support}

Description and Cause: The favorable cost variance $(\$ 4.4 \mathrm{M} ; 9.1 \%)$ results from a credit passback for approved reductions in the Fluor Hanford and $\mathrm{CHG}$ overhead pools; and efficiencies gained through better utilization of resources in Construction Project Management, Systems Engineering and Technical Baseline, and Project Integration Office activities.

Impacts: There are no impacts.

Corrective Action: None required, as efficiencies were used for other higher priority work 


\section{MILESTONE ACHIEVEMENT}

\begin{tabular}{|c|c|c|c|c|c|c|c|c|}
\hline Type & \multicolumn{4}{|c|}{ Fiscal Year To Date } & \multicolumn{3}{c|}{ Remaining } & $\begin{array}{c}\text { Total } \\
\text { FY 2000 }\end{array}$ \\
\hline & $\begin{array}{c}\text { Completed } \\
\text { Early }\end{array}$ & $\begin{array}{c}\text { Completed } \\
\text { on Schedule }\end{array}$ & $\begin{array}{c}\text { Completed } \\
\text { Late }\end{array}$ & Overdue & $\begin{array}{c}\text { Forecast } \\
\text { Early }\end{array}$ & $\begin{array}{c}\text { Forecast on } \\
\text { Schedule }\end{array}$ & $\begin{array}{c}\text { Forecast } \\
\text { Late }\end{array}$ & \\
\hline $\begin{array}{c}\text { TPA- } \\
\text { Major }\end{array}$ & 1 & 0 & 0 & 0 & 0 & 0 & 0 & 1 \\
\hline $\begin{array}{c}\text { TPA- } \\
\text { Interim }\end{array}$ & 10 & 1 & 1 & 0 & 0 & 0 & 0 & 12 \\
\hline $\begin{array}{c}\text { Consent } \\
\text { Decree }\end{array}$ & 1 & 1 & 0 & 0 & 0 & 0 & 0 & 2 \\
\hline $\begin{array}{c}\text { DOE- } \\
\text { ORP }\end{array}$ & 23 & 22 & 3 & 4 & 0 & 0 & 0 & 52 \\
\hline Total & 35 & 24 & 4 & 4 & 0 & 0 & 0 & 67 \\
\hline
\end{tabular}

Note: This milestone count is based on the approved FY 2000 Bridge Change Request RPP-00-003, and any subsequent approved BCRs. Tri-Party Agreement Major and Interim, and Consent Decree milestones reflect the enforceable agreement dates.

\section{Milestone Exceptions}

OVERDUE - 4

MS No. Level Milestone Title

T03-00-755 ORP

1.01 .03

Cause: Pumping efficiency was not met due to equipment failures.

Impact: There are no impacts at this time.

Corrective Action: Work continued to meet the fourth quarter pumping efficiency milestone T03-00-756, due September 30, 2000.

T04-00-107 ORP Perform a Gap Analysis (ORP 4.5.1) 6/15/00

To be deleted

1.01 .04

Cause: DOE-ORP canceled this work based on the BNFL contract termination.

Impact: There are no impacts.

Corrective Action: A BCR will be prepared to delete this milestone. 


\section{Milestone Exceptions (continued)}

Baseline

Date

$9 / 30 / 00$

\section{Forecast}

Date

T04-00-343 ORP

Develop SST Program

Capabilities and Evaluation

1.01 .04

Cause: This milestone is being deleted due to higher priority work and SST renegotiations.

Impact: There are no impacts.

Corrective Action: A BCR will be prepared to delete this milestone.

T06-00-101 ORP

Construction Authorization

$8 / 24 / 00$

$1 / 15 / 00$

1.01 .06

Program Review/Decision

Cause: The BNFL contract has been terminated; therefore, construction authorization will not be awarded this fiscal year.

Impact: Privatization milestones are being re-negotiated.

Corrective Action: This milestone will be re-established in FY01. A Request for Proposal for construction of the vitrification plant is in process. Award of the contract is anticipated in December 2000 . 


\section{Section III}

\section{Waste Treatment and Immobilization Plant (WTP)}

CH2M HILL Hanford Group,
Inc. (CHG)

PROJECT MANAGER:

M. P. Delozier President and General Manager CH2M HILL Hanford Group, Inc. Phone: (509) 372-8061 


\section{Waste Treatment and Immobilization Plant (WTP) CH2M HILL Hanford Group, Inc. (CHG)}

CH2M HILL Hanford Group, Inc. (CHG) successfully completed the orderly transition of the River Protection Project - Waste Treatment and Immobilization Plant project in accordance with performance incentive ORP 6.1.2. This transition is the result of the U.S. Department of Energy (DOE) termination of its contract with BNFL Inc. CHG has been assigned the work scope for system integration, continuing the interim design effort during the selection of and transition to a new design and construction contractor, and operations for the Waste Treatment and Immobilization Plant project design.

An approved Baseline Change Request updated the CHG baseline to include the balance of the FY 2000 WTP work scope. The costs and schedule included in this report will be reported against this work. Another $\mathrm{BCR}$ is being developed which will update the $\mathrm{CHG}$ lifecycle baseline to include the work scope for the design and operation of the WTP.

\section{SCHEDULE PERFORMANCE}

\begin{tabular}{|l|c|c|c|}
\hline & BCWP & BCWS & VARIANCE \\
\hline WTP TOTAL & $\$ 31.4$ & $\$ 31.4$ & $\$ 0$ \\
\hline
\end{tabular}

\section{SCHEDULE VARIANCE}

Nothing to report.

- COST PERFORMANCE

\begin{tabular}{|l|c|c|c|}
\hline & BCWP & ACWP & VARIANCE \\
\hline WTP TOTAL & $\$ 31.4$ & $\$ 21.7$ & $\$ 9.7$ \\
\hline
\end{tabular}

\section{COST VARIANCE}

The positive cost variance is primarily due to:

- Subcontract costs substantially less than estimated for R\&T activities due to delays in contract award and contractual issues with the GTS-Duratek Pilot Melter in the area of R\&T.

- Delay in obtaining planned staff-augmentation support for Interim Design activities due to the CHG WTP self-imposed stop work of quality-affecting and ITS work. 


\section{WTP UPCOMING KEY PLANNED EVENTS IN THE NEXT 90 DAYS}

- CHG shall prepare an updated integrated DRD similar in format and level of detail to the original deliverable B-1-6, submitted by BNFL Inc., to DOE on 11/17/98.

- CHG is to identify those new testing activities it proposes to begin. This submission, which will be part of the interim design and transition work plan, should identify for each specific testing activity the following information.

- Purpose and Scope of Test

- Budget for Testing Activity

- Performing Organization

- Permitting

- Safety Analysis

- Operations and or

- Waste Qualification activities

- The design deliverables provided to the DOE on $4 / 24 / 00$ shall be updated to include information as of $6 / 29 / 00$ or later. These design deliverables are to be organized in design packages based on system numbers. See Sections 6.4.1 through 6.4.5

- The following design products shall be updated and organized in a logical manner.

- Ventilation and Instrumentation Diagrams (void's)

- Instrument schedules

- Electrical Single line Diagrams

- Electrical Load Schedules

- Hydraulic Gradient Diagrams for interceding piping between facilities

- Mechanical Flow Diagrams (MFDs)

- Material Handling Diagrams (MHDs)

- Design Proposal Drawings (Equipment Procurement Drawings)

- A multi-disciplined design review shall be scheduled, conducted, and documented. A list of systems to be reviewed will be developed by CHG and agreed to by DOE.

- CHG shall verify and document to DOE that the OR Model accurately reflects the baseline process and facility.

- The G2 Model is to be developed and documented to model the utilization of tank capacity cycle times in the Treatment and Immobilization Facilities.

- The ASPEN Model is to be developed and documented to model the mass and activity balance in the Treatment and Immobilization Facilities.

- The sampling and analysis requirements to support process control, environmental compliance and waste form qualification shall be further developed and provided to the DOE.

- Develop draft responses to regulator comments on the Vitrification Plant Combustion Risk Assessment Work Plan.

- CHG shall plan on providing extensive briefings to the WTP contractor on the work scope being transitioned.

- CHG shall conduct the following activities to support staff transition to the final WTP contractor.

- Identify staff acquired from Privatization Contract for Conceptual Design that will be available for reassignment.

- Provide a summary-level description of the capabilities of the acquired staff.

- Identify subcontractors acquired from privatization contract associated with WTP Conceptual Design along with their subcontractor organization, scope of work, contract dollar value during transition period, and number of subcontract staff involved in the work.

- The WTP Contractor shall begin to occupy the 3000 George Washington Way facilities previously used by BNFL and currently being used by CHG. 


\section{WTP UPCOMING KEY PLANNED EVENTS IN THE NEXT 90 DAYS (Continued)}

- The Operations Costs shall be reviewed to ensure that there is an accurate portrayal of the necessary work scope, costs of labor are consistent with the current CHG rates, operator efficiency is consistent with current or anticipated work scope efficiencies, and to ensure that operations of the facility is consistent with the planning associated with Tank Farm Operations.

- Changes to the operations cost estimate shall be documented at the lowest level of the current estimate. The cost estimate need not be broken down to lower levels. Changes shall not be summarized at high levels of the estimate without the requisite detail at the lower levels. Changes to the cost estimate shall be documented consistent with the process used by BNFL. Revision to the applicable Scoping Statements shall be provided to support the proposed cost changes. Conversion of the Scoping Statements to Technical Baseline Reviews are not required nor desired.

- Review the BNFL schedule and identify those activities that are unduly constrained. Revise the schedule to minimize the number of constrained activities. Maintain a document that shows the changes that are made to schedule.

- Review the BNFL Level 2 schedule to determine if the schedule can be matured to a point where it can be considered a level 3 schedule. Maintain a document that shows the changes that are made to schedule.

- CHG shall provide to DOE glass information developed with Contract (DE-AC27-96RL13308) funds since September 1996 (start of Part A), including, but not limited to: Composition, viscosity's as a function of temperature, durability test results (PCT; TCLP, VHT) etc. See Section 9 (a) through ( $f$ )

- During the interim design period and to be completed as a milestone deliverable by $1 / 15 / 01, \mathrm{CHG}$ is to continue to develop the process design in accordance with the following guidance. See 6.6.9.1 and 6.6.9.2.

- Facility Design Products shall also be provided to DOE as part of the design review process milestone deliverables. See 6.6.10.1 through 6.6.10.3.

- Balance of Facility Design shall be updated and provided to DOE. See 6.6.11.1 through 6.6.11.3.

- Revise the Products and Secondary Wastes Plan incorporating DOE's comments (Reference Letter, 00-PRD-040 dated May 25, 2000), and submit a revised Products and Secondary Wastes Plan to DOE for concurrence.

- Revise the Waste Form Compliance Plan (WCP) incorporating DOE's comments (Reference Letter, 00-PRD-034 dated May 19, 2000 and obtain DOE concurrence.

- Update the Waste Form Qualification Report (WQR) incorporating DOE's comments (Reference Letter, 00-RPD-051, dated June 27, 2000) for DOE review and comment. See Section 4). 


\section{DISTRIBUTION COVERSHEET}

\begin{tabular}{llcc}
$\begin{array}{l}\text { Author } \\
\text { S. C. Johnson }\end{array}$ & $\begin{array}{l}\text { Addressee } \\
\text { See attached list }\end{array}$ & $\begin{array}{l}\text { Correspondence No. } \\
\text { DOE/ORP }\end{array}$ \\
Subject: & Office of River Protection & \\
& Monthly Performance Report - September 2000 \\
\hline Name & DISTRIBUTION & Location & w/att \\
\hline
\end{tabular}

Central Files $\quad$ B1-07

DPC H6-08

DOE Reading Rm. H2-53

Hanford Tech. Lib. P8-55 